\title{
Lymphocyte Subpopulations in Otitis Media with Effusion
}

\author{
J. M. BERNSTEIN, C. SZYMANSKI, B. ALBINI, M. SUN, AND P. L. OGRA ${ }^{(15)}$ \\ Departments of Pediatrics, Microbiology, Otolaryngology, and Pathology, State University of New York at Buffalo; \\ and Division of Clinical Infectious Disease and Virology, Children's Hospital of Buffalo, Buffalo, New York, USA
}

\begin{abstract}
Summary
The distribution of $B$ and $T$ lymphocytes and macrophages in the middle ear fluid (MEF) was studied in groups of children with otitis media associated with serous, seromucinous, or mucoid effusions in the middle ear. The subpopulations of $T$ and $B$ lymphocytes and macrophages were identified in the MEF by employing the techniques of spontaneous erythrocyte rosetting (E), membrane immunofluorescence, erythrocyte-amboceptorcomplement (EAC) and erythrocyte-amboceptor (EA) rosette formation, respectively. A significant number of $B$ and $T$ lymphocytes or macrophages were detected in all specimens; however, certain differences were observed in their relative distribution in different types of effusions. Serous MEF was characterized by a cellular response associated predominantly with macrophages, although $T$ lymphocytes were also seen frequently. No B lymphocytes were seen in such exudates. The seromucinous MEF contained $B$ and $T$ lymphocytes and macrophages in approximately similar proportions. Significantly, however, the mucoid effusion consisted mainly of B lymphocytes. Only macrophages and no $\mathrm{T}$ cells were observed in these effusions. The cytologic findings reported here may be helpful in a more definitive classification of middle ear effusions. These data may suggest a possible role of the different components of cellular immunity in the development of middle ear effusions.
\end{abstract}

\section{Speculation}

E rosette-forming cells predominate in the serous and seromucinous effusions of otitis media. EAC rosette-forming cells appeared as a predominant cell type in mucoid effusions. The different types of effusions in otitis media may represent the various stages of the same inflammatory process. The differences in the types of immunocompetent cells observed may reflect the nature of the underlying immune response in serous, seromucinous, or mucoid forms of otitis media.

Presently, otitis media with effusion is the most common cause of acquired hearing loss in children (4). There is a paucity of information concerning the immunologic mechanisms involved in middle ear effusions. Various immunologic mechanisms are known to be present in the middle ear mucosa $(1,10)$. However, their specific function in the formation of MEF is not yet clarified.

Senturia (11) has emphasized that a proper classification of middle ear effusions is an important prerequisite to a rational approach to prophylaxis and treatment of otitis media. Furthermore, it has been suggested that the etiology and the developmental sequence of pathologic changes observed in the middle ear may be different for each of the suggested categories of middle ear effusions.

Initial work from our laboratory relating to the secretory immune system in the middle ear has focused largely on the presence and development of the secretory immunoglobulins in the middle ear effusions, particularly IgA, and their possible role in the immunity or defense against local infections $(1,2,10)$. The present studies were undertaken to analyze the distribution and nature of immunocompetent cells in different forms of middle ear inflammation in an effort to establish guidelines for classification of otitis media with effusion.

\section{MATERIALS AND METHODS}

\section{STUDY POPULATION}

Therapeutic myringotomy and aspiration of MEF was performed on 40 children with otitis media. The subjects ranged from 8 months to 13 years of age and represented males and females in approximately equal numbers. Following the aspiration, the MEF was cleared of mucin and fibrin by vigorous stirring with glass beads and centrifugation at $500 \mathrm{rpm}$ for $10 \mathrm{~min}$. The supernatant was removed and the cellular pellet resuspended in Roswell Park Memorial Institute medium 1640 (RPMI 1640, Grand Island Biological Company, Grand Island, NY). The middle ear sediments were then washed twice with Hanks' balanced saline solution (HBSS) and then twice with gelatin Veronol buffer with calcium and magnesium $\left(\mathrm{GVB}^{++}\right)$and resuspended to a concentration of 1 million cells $/ \mathrm{ml}$ when possible.

Table 1 summarizes the different types of MEF used in the study. The serous effusions were characterized by a thin straw- or salmon-colored fluid with very low viscosity. A few neutrophils and a few mononuclear cells were seen in the sediment. The seromucinous variety was characterized by a cloudy fluid of low viscosity, and usually possessed neutrophils and mononuclear cells in approximately equal proportions. The mucoid variety consisted of a thick tenacious glue-like material in which mononuclear cells predominated.

\section{CYTOLOGY OF MIDDLE EAR SEDIMENTS}

An aliquot of MEF was fixed in $70 \%$ alcohol and submitted for cytocentrifugation. The centrifuged sediment was then stained with Wright solution and 100 cells were counted.

The cell suspensions were examined for B cells, $T$ cells, and macrophages by rosetting and by surface immunoglobulin staining techniques as described below.

\section{SPONTANEOUS SHEEP ERYTHROCYTES (E ROSETTES)}

The $T$ lymphocytes in MEF were detected by sheep erythrocyte rosetting techniques $(12,13)$. Briefly, $0.5 \mathrm{ml}$ MEF cell suspension was mixed with an equal volume of $0.5 \%$ washed sheep erythrocyte suspension in $\mathrm{GVB}^{++}$. The mixture was incubated at $37^{\circ}$ for 15 min and centrifuged for $5 \mathrm{~min}$ at $200 \times \mathrm{g}$, followed by overnight incubation at $4^{\circ}$. The pellets were gently resuspended and the percentage of $E$ rosette-forming (E) cells was calculated by counting at least 200-300 lymphocytes under the microscope.

\section{EA ROSETTE PREPARATION}

Sheep red cells were incubated with an equal volume of IgG anti-sheep erythrocyte antibody (Cordis Laboratory, Miami, FL). 
Table 1. Classification of middle ear effusions

\begin{tabular}{lcc}
\hline MEF type & $\begin{array}{c}\text { No. of } \\
\text { MEF } \\
\text { tested }\end{array}$ & \multicolumn{1}{c}{ Description } \\
\hline Berous & 10 & $\begin{array}{c}\text { Straw colored low viscosity, few neu- } \\
\text { trophils, few mononuclear cells }\end{array}$ \\
Seromucinous & 16 & $\begin{array}{c}\text { Low viscosity, cloudy yellow, few } \\
\text { neutrophils, many mononuclear } \\
\text { cells }\end{array}$ \\
Mucoid & 16 & $\begin{array}{c}\text { Thick, tenacious material, mainly } \\
\text { mononuclear cells in sediment }\end{array}$ \\
\hline
\end{tabular}

The concentration of IgG antibody employed ranged from 1:3000-1:4500 agglutination titers. The EA rosetting was performed by mixing $0.5 \mathrm{ml} \mathrm{MEF}$ with an equal volume of a $2.5 \%$ suspension of antibody coated sheep red cells incubated at $37^{\circ}$ for $30 \mathrm{~min}$ (7). The percentage of EA rosette forming cells was calculated by counting 200-300 lymphocytes under the microscope.

\section{EAC ROSETTE PREPARATION}

Sheep red cells were incubated with IgM rabbit anti-sheep erythrocyte antibody (Cordis Laboratory). After incubation for 30 min at $37^{\circ}$, the EAC cells thus formed were incubated for an additional $1 \mathrm{hr}$ with 1:10 dilution of fresh normal mouse serum diluted with $\mathrm{GVB}^{++}(12)$. Subsequently, $0.5 \mathrm{ml} \mathrm{MEF}$ suspension was incubated with an equal volume of a $2.5 \%$ suspension of $E A$ cells at $37^{\circ}$ for $30 \mathrm{~min}$. The pellets were gently resuspended and the percentage of EAC rosette-forming cells was calculated by counting at least 200-300 lymphocytes under the microscope.

\section{SURFACE IMMUNOFLUORESCENCE OF MEF CELLS}

MEF sediments were suspended in $\mathrm{GVB}^{++}$so that a concentration of approximately $5 \times 10^{6}$ cells $/ \mathrm{ml}$ was obtained. The cell suspension was incubated with an equal volume of rabbit antiserum specific for heavy chains of human immunoglobulin (Cappel Laboratories, Downington, PA). Incubation was carried out at room temperature for $30 \mathrm{~min}$ after adding $7 \mu \mathrm{mol}$ sodium azide to prevent capping. The suspension was then washed twice in RPMI 1640 and then again twice in phosphate-buffered saline (PBS) at a $\mathrm{pH}$ of 7.2. A drop of this mixture was then placed on a slide under a coverslip with buffered glycerol. The suspension was counterstained with Evan's blue. Approximately, 200-300 cells were counted under an optical system consisting of a ReichertZetopan fluorescence microscope equipped with a HBO-200 mercury vapor bulb. A Balzer FITZ-3 exciter filter (range 400-480 $\mathrm{nm}$ ), an OG 515 barrier filter (wedge at $513 \mathrm{~nm}$ ) and a dark field condenser was used throughout these experiments.

\section{BACTERIOLOGY OF MEF}

Aliquots of $25 \mathrm{MEF}$ specimens processed under sterile conditions were tested for both anaerobic and aerobic bacterial organisms.

\section{RESULTS}

\section{TOTAL CELLS}

The total cell count varied from $4 \times 10^{5} / \mathrm{ml}$ in the serous variety to about $1 \mathrm{million} / \mathrm{ml}$ in the seromucinous variety (Table 2). Although the bulk of the cellular elements in the MEF consisted of macrophages and lymphocytes, in a few MEF specimens polymorphonuclear leukocytes constituted $50-80 \%$ of the total cells.

\section{ROSETTE-FORMING CELLS}

The distribution of E, EA, and EAC rosetting cells in different MEF specimens is presented in Table 3. T lymphocytes as evidenced by $\mathrm{E}$ rosetting were primarily found in serous and seromucinous varieties of MEF. As many as $45 \%$ of $T$ cells were found in such MEF specimens, and very few $T$ cells were observed in mucoid effusions. The distribution of $B$ cells based on the proportion of EAC rosette-forming cells from which EA rosetting cells were excluded, indicated that serous and seromucinous forms of MEF contained 3-8\% B lymphocytes, and their mean values were 3- to 4-fold higher in mucoid effusions (Table 3).

The distribution of macrophages as evidenced by the proportion of EA rosette forming cells was approximately similar in all forms of MEF specimens tested. The individual numbers ranged from 5 to $76 \%$ of total cells and the mean numbers ranged from 30 to $35 \%$ (Table 3).

\section{SURFACE IMMUNOGLOBULIN-STAINING CELLS}

The distribution of B lymphocytes was determined in several other samples of MEF by simultaneous testing by rosetting and surface immunoglobulin staining (SIg). As shown in Table 4, little or no SIg-staining cells were observed in serous MEF. About $17 \%$ of SIg-staining cells were observed in seromucinous effusions. Significantly, however, the number of SIg-staining lymphocytes in mucoid effusions was over $80 \%$. Cells staining for IgG immunoglobulin were seen more commonly than IgA and IgM bearing B lymphocytes (Table 4).

\section{BACTERIOLOGY}

Approximately $80 \%$ of specimens of serous, seromucinous and mucoid effusions tested to date have failed to yield any anaerobic or aerobic bacteria. However, it should be pointed out that all these subjects had received antibiotic therapy for varying lengths of time before the collection of MEF. No specific correlation existed between the nature and cellular content in MEF and the types of organisms recovered in the remaining bacteriologically positive MEF specimens.

\section{DISCUSSION}

Inasmuch as the monocyte macrophage series as well as the B lymphocytes possess a receptor for the third component of complement, it would be impossible to distinguish between the mac-

Table 2. Average cell counts in middle ear effusions

\begin{tabular}{lcc}
\hline \multicolumn{1}{c}{ Type } & $\begin{array}{c}\text { No. of MEF } \\
\text { tested }\end{array}$ & $\begin{array}{c}\text { Mean } \\
\text { (total no. cells } / \mathrm{ml} \text { ) }\end{array}$ \\
\hline Serous & 10 & $4 \times 10^{5}$ \\
Seromucinous & 16 & $1 \times 10^{6}$ \\
Mucoid & 10 & $6 \times 10^{5}$ \\
\hline
\end{tabular}

Table 3. Distribution of $T$ and $B$ lymphocytes and macrophages in different middle ear effusions

\begin{tabular}{lcccc}
\hline & & \multicolumn{3}{c}{$\begin{array}{c}\text { \%osette-forming cells } \\
\left(\frac{\text { range }}{\text { average }}\right)\end{array}$} \\
\cline { 3 - 5 } MEF type & $\begin{array}{c}\text { No. of } \\
\text { MEF } \\
\text { tested }\end{array}$ & E (T cell) & $\begin{array}{c}\text { EAC-EA } \\
\text { (B cell) }\end{array}$ & $\begin{array}{c}\text { EA (macro- } \\
\text { phage })\end{array}$ \\
\hline Serous & 15 & $\frac{9-45}{27}$ & $\frac{0-25}{3}$ & $\frac{5-76}{35}$ \\
Seromucinous & 12 & $\frac{2-45}{19}$ & $\frac{0-23}{8}$ & $\frac{17-48}{30}$ \\
Mucoid & 16 & $\frac{0-12}{3}$ & $\frac{5-30}{20}$ & $\frac{8-63}{33}$ \\
\hline
\end{tabular}


Table 4. Distribution of $T$ and $B$ cells and macrophage and SMIg in 14 middle ear fluids

\begin{tabular}{|c|c|c|c|c|c|c|c|c|}
\hline \multirow[b]{2}{*}{ MEF type } & \multirow[b]{2}{*}{$\begin{array}{c}\text { No. of MEF } \\
\text { tested }\end{array}$} & \multicolumn{3}{|c|}{ Mean \% rosette-forming cells } & \multicolumn{4}{|c|}{ Mean \% SMIg (B cell) } \\
\hline & & $\mathrm{E}$ ( $\mathrm{T}$ cell) & $\begin{array}{c}\text { EAC-EA } \\
\text { (B cell) } \\
\end{array}$ & $\begin{array}{c}\text { EA (macro- } \\
\text { phage) }\end{array}$ & IgG & IgA & IgM & Total \\
\hline Serous & 4 & 15 & 0 & 85 & 1 & 0 & 0 & 1 \\
\hline Seromucinous & 4 & 17 & 15 & 68 & 13 & 3 & 1 & 17 \\
\hline Mucoid & 6 & 1.5 & 75 & 20 & 56 & 20 & 6 & 82 \\
\hline
\end{tabular}

rophage monocyte cells and the $B$ lymphocytes on the basis of the EAC rosetting alone. Shevach et al. (12) have demonstrated that binding site for the macrophage resides on the Fc fragment of $\mathrm{IgG}$, and a combination of IgG rabbit antibody to sheep erythrocyte can thus be used for the demonstration of the Fc receptor on the macrophage. According to Shevach et al., this will not occur with the B lymphocyte population of humans and, therefore, the EA rosette formed with sheep red cells will adhere to the human macrophage exclusively. By subtracting the number of EA rosettes from EAC rosettes, the number of B lymphocytes can be found. Our experience also suggests that under the experimental conditions described and using rabbit IgG antibody against sheep red cell stroma, EA rosettes adhere only to the monocyte-macrophage cells and not to the B lymphocytes. On the other hand, Coombs and Frank (5), using ox erythrocytes, have reported that the EA rosettes do adhere to the human $B$ cells. The difference in this technique and ours may be related to the decreased avidity of the $\mathrm{Fc}$ receptor of $\mathrm{B}$ cells for $\mathrm{IgG}$, or to a difference in IgG subclasses. The studies reported here suggest that middle ear effusions possess both $\mathrm{T}$ and $\mathrm{B}$ lymphocytes and macrophages.

The cellular immune response in otitis media after the onset of inflammation has not been established. Furthermore, there is little information available regarding the role of immune mechanisms in protection or in the immunopathogenesis of otitis media.

The present data suggests that the cellular immune response in otitis media with effusion is mainly mononuclear and that there are differences in the lymphocyte subpopulations in each type of effusion studied. The serous effusion consisted mainly of $\mathrm{T}$ cells and the mucoid effusions contained predominantly B cells. Macrophages were found in all forms of MEF. Furthermore, B lymphocytes in the mucoid effusion appear to be essentially of IgG and IgA classes. This would be in keeping with the immunofluorescent data noted in the tissue biopsies where plasma cells appear to be synthesizing mainly $\operatorname{IgA}$ and $\operatorname{IgG}(9)$.

The importance of MEF lymphocytes is not clear. The presence of $\mathrm{T}$ cells, mainly in serous and seromucinous effusions may suggest that a $\mathrm{T}$ cell-mediated immune response is associated with these effusions. Such a response occurs early in the course of otitis media. In this regard, it is interesting to note that following immunization with rubella virus, Morag et al. (8) have found that the cellular immune response preceded antibody synthesis after antigenic challenge. Thus, the cell mediated response may precede a humoral response in inflammation in general, suggesting that the serous and seromucinous effusions represent an early form of otitis media.

It is known that the immune response in otitis media with effusion is a local one in which secretory immunoglobulins are present (10). Furthermore, the mean concentration of $\mathrm{IgG}$ and $\operatorname{IgA}$ in MEF is $2-3$ times that of the serum concentration $(3,6)$. The B lymphocyte activity in MEF may, therefore, represent a late humoral immune response in middle ear inflammations. Based on these data, a possible approach to the classification of MEF is suggested in Table 5 . The immediate response to the middle ear inflammation is usually an outpouring of polymorphonuclear leukocytes into the middle ear cleft from the blood stream. Very few lymphocytes are present, but when present are usually of the T cell type. A later stage in the disease would be the serous and seromucinous response, in which mainly $T$ cells and macrophage predominate. Finally, the late stage of otitis media could be
Table 5. Immune response in otitis media with effusion based on available data

\begin{tabular}{lll}
\hline $\begin{array}{c}\text { Stage of dis- } \\
\text { ease }\end{array}$ & Type of effusion & \multicolumn{1}{c}{ Immune response } \\
\hline Very early & Purulent & Neutrophils, few T Cells \\
Early & Serous & $\begin{array}{c}\text { T cells; macrophages (cell-me- } \\
\text { diated response?) }\end{array}$ \\
Intermediate & Seromucinous & $\begin{array}{c}\text { T cells, B cells; macrophages (cell- } \\
\text { mediated and humoral immu- } \\
\text { nity?) }\end{array}$ \\
Late & Mucoid & B cells; some macrophages (hu- \\
moral immunity?)
\end{tabular}

the mucoid effusion, characterized mainly by B cells and macrophages.

Whether these varieties of otitis media are different stages of the same inflammatory response, or represent different immunopathologic disease entities cannot be clearly defined at this time. Additional studies are in progress to explore the observations in further detail in an experimental model of otitis media.

\section{REFERENCES AND NOTES}

1. Bernstein, J. M., Tomasi, T. B., and Ogra, P.: The immunochemistry of middle ear effusions. Arch. Otolaryngol., 99: 320 (1974).

2. Bernstein, J. M., Hayes, R., Ishakawa, T., et al.: Secretory otitis media, a histopathologic and immunochemical report. Trans. Amer. Acad. Opthalmol. Otolaryngol., 76: 1305 (1972).

3. Bernstein, J. M., Shenkheim, H., Genco, R., and Bartholomew, W.: Complement activity in middle ear effusions. (Submitted for publication.)

4. Bluestone, C. D., Paradise, J. L., and Berry, Q. C.: Physiology of a eustachian tube in the pathogenesis and management of middle ear effusions. Laryngology, 82: 1654 (1972).

5. Coombs, R. R. A., and Frank, D.: Immunological reaction involving two cell types. Prog. Allergy, 13: 174 (1969).

6. Liu, S. Y., Lim, D. J., Lang, R. W., and Burke, H. G.: Chronic middle ear effusions: Immunochemical and bacteriological investigations. Arch. Otolaryngol., 101: 278 (1975)

7. LoBuglio, A. F., Cotran, R. S., and Jandl, J. H.: Red cells coated with immunoglobulin G: Binding and sphering by mononuclear cells in man. Science, 158 : 1582 (1967).

8. Morag, A., Beutner, K. R., Morag, B., and Ogra, P. L.: Development and characteristics of in-vitra correlates of cellular immunity to Rubella virus in the systemic and mucosal sites of guinea pig. J. Immunol., 113: 1703 (1974).

9. Mogi, G., Hongo, S., Maeda, S., et al:: Secretory immunoglobulin A (SIgA) in middle ear effusions. Ann. Otol. Rhinol. Laryngol., 82: 302 (1973).

10. Ogra, P. L., Bernstein, J. M., Yurchak, A. M., Coppola, P. R., and Tomasi, T. B.: Characteristics of secretory immune system in human middle ear: Implications in otitis media. J. Immunol., 112: 488 (1974).

11. Senturia, B. H.: Classification of middle ear effusions. Ann. Otol. Rhinol. Laryngol., 79: 358 (1970).

12. Shevach, E. M., Jaffe, E. S., and Green, I.: Receptors for complement and immunoglobulin on human and animal lymphoid cells. Transplant. Rev., 16: 3 (1973).

13. Yu, D. T. Y.: Human lymphocytes subpopulation; Early and late rosettes. J. Immunol., 115: 91 (1975).

14. This research was supported by Grants AM17050-3, HD10088-1, and AI-32522 from the NIH.

15. Requests for reprints should be addressed to: Dr. P. L. Ogra, Children's Hospital of Buffalo, 219 Bryant Street, Buffalo, NY 14222 (USA).

16. Received for publication January 4,1977

17. Accepted for publication October, 5, 1977. 